\title{
Identifying The Traits Of Entrepreneurs In A University Setting: An Empirical Examination Of Saudi Arabian University Students
}

Mohammed Al-Habib, King Abdulaziz University, Saudi Arabia

\begin{abstract}
The study of entrepreneurs and entrepreneurship has recently attracted the attention of scholars from diverse fields such as sociology, anthropology, and business. Much of the research conducted has been focused on entrepreneurial motivation and personal characteristics in developed countries. In this paper, we examine the relationship between four personality characteristics - Innovativeness, risk-taking, locus of control and energy level, and the likelihood of owning or starting a business.

Utilizing a sample of 600 students attending three universities in Saudi Arabia and a selfadministered questionnaire, the present study's results show systematic variation in entrepreneurial characteristics across groups of university student entrepreneurs and nonentrepreneurs. Student entrepreneurs are more likely to be innovative, risk-takers, and exhibit high levels of energy and locus of control than their non-entrepreneurs counterparts.

The results of the study raise important questions about the identification and targeting of potentially successful entrepreneurs and the appropriate mechanism for aiding them in realizing their dreams to become successful business owners capable of creating new jobs and fueling economic growth.
\end{abstract}

Keywords: Entrepreneur Traits; University Students; Developing Countries and Saudi Arabia

\section{INTRODUCTION}

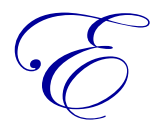

ntrepreneurs and owners of small and medium size enterprises (SMEs) can contribute to the economic growth of the developed and developing economies alike. These firms play an important role in generating employment, creating income for a large portion of low-income segments of the economy, and filling the domestic demand for low-cost goods and services. The success, therefore, of the SME sector significantly impacts the economy of a country as a whole.

SMEs in developing countries are in their infancy while SMEs in the U.S and other developed countries have achieved substantial support from the private and public sectors that helped them grow and contribute positively to their economies. SMEs in developing countries still face a number of constraints to growth. These constraints include a lack of basic skills, lack of entrepreneurial talent, and shortage of capital. Additionally, there is restricted access to financing and poor information regarding market opportunities and requirements.

The present study aims at identifying the personality traits of potential entrepreneurs among college students using Saudi Arabia as a case study. The outcome of the study will include an assessment of the key chrematistics of potential entrepreneurs. These characteristics can be used as a diagnostic tool tailored to screening non-entrepreneurs from entrepreneurs. 
Saudi Arabia, an oil rich developing country, has historically used oil revenue to solve deeply rooted economic problems (e.g., young population with $65 \%$ below the age of 18 years, $35 \%$ unemployment rate among this young population, limited public sector capacity to absorb population growth by providing meaningful job opportunities, lack of a well-developed private sector that can lend a hand in solving these problems, etc). However, fluctuations in oil prices and the subsequent danger of dependency on a single source of revenue to sustain economic development and growth has brought forward the role of the private sector in the country's economic development to public policymakers in Saudi Arabia. In fact, the Saudi eighth Five-Year Plan for 2005-2010 lays out the proposal for a private sector-led growth that shifts the economic development burden from the public to the private sector. The development and enhancement of small and medium size enterprises is in the center of the model for private sector-led growth.

In support of this newly adopted economic development model, several government initiatives were introduced. These initiatives include the establishment of the Centennial Fund, a government funded agency that provides technical and financial support to SMEs; the recent creation of the Saudi Small Business Administration that is modeled after the United States Small Business Administration (USSBA); and the expansion of the nature and scope of Lending Bank to primarily focus on enhancing credit extension to SMEs in Saudi Arabia. While these initiatives are commendable and exciting, SMEs in Saudi Arabia still face a number of constraints to growth, such as lack of entrepreneurial talent, basic skills, capital, research and development facilities, and poor information about market opportunities, and requirements and restricted access to financing. These issues are not unique to Saudi SMEs. However, to date there is no means of identifying young individuals with potential for creating a sustainable entrepreneurship venture. In order to help this group to overcome the constraints they face, systematic and comprehensive studies are necessary to clearly identify the individuals so commendable government initiatives can be directed at them.

\section{LITERATURE REVIEW}

Given the limited research conducted in Saudi Arabia on this important topic, the literature review will be organized around evidence gathered from previous research on SME development in developing countries, as well as recent initiatives introduced by the Saudi government to ignite and enhance the growth of this sector. More specifically, the literature review will address the following four major issues:

1. role of entrepreneurs in society

2. role of Entrepreneurs in Saudi Arabia

3. Saudi government policies enhancing entrepreneurship

4. $\quad$ traits of entrepreneurship

\section{Role of Entrepreneurs in Society}

Starting as entrepreneurial activities, there are many examples of big businesses in the areas of IT, engineering, sciences, and several other disciplines across the globe that later shaped major industries - e.g. Best Buy, one of the world's largest US-based retailers of electronic goods and services, started as an entrepreneurial activity. Google started off as a Ph.D. project at Stanford University and, over time, became an extremely successful business. Other examples, such as Virgin group from the UK, Tata, Reliance, and Mittal group of industries from South Asia bear testimony to the above statements.

Interestingly, the above examples suggest that if certain individual and environmental conditions are met, and if the individuals with entrepreneurial initiatives receive formal training, these initiatives may be born, sustained, nurtured, and grown in many different areas/industries. Entrepreneurship literature has long studied the conditions that are conducive to creating an entrepreneur in society. Research has looked at individual-level factors such as motivation, entrepreneurial spirit, personality traits (Schumpeter 1934), as well as broader environmental factors such as national or societal culture (Herbig, 1994), supportive infrastructure (Tadeo 2004), and legal and regulatory environment (Tolentino, 1995; Hallberg, 2000), among others, that may stimulate entrepreneurial activities within society. 
Some important questions may arise in this regard:

1. Why is the presence of entrepreneurs and formal entrepreneurship education to budding entrepreneurs so important in today's context?

2. What roles do entrepreneurs play and how does their presence benefit the broader society as such?

Research shows that new business creation is a fundamental indicator of entrepreneurial activity in the U.S. economy. Needless to say, new business creation is a quintessential entrepreneurial activity. Self-sufficiency and independency lead individuals to create new businesses playing a significant role in triggering the economic growth, innovation and job creation that affects the broader society as such. According to the Global Entrepreneurship Monitor (GEM), in a multi-year comparison of entrepreneurial activity across countries, new business creation is highly associated with economic growth around the world (http://www.kauffman.org). A 2007 State New Economy Index released by the Kauffman Foundation (http://www.kauffman.org/items.cfm?itemID=766) states that within the US, states at the top of the developmental ranking tend to have a high concentration of managers, professionals, and college-educated residents working in "knowledge jobs." The report further argues that all the states at the top of this ranking also show above-average levels of entrepreneurship within their communities. Historical research attests to the fact that innovation and job growth in most U.S. industries come from new entrepreneurial businesses rather than from larger, well-established companies. David Birch's 1979 study of the impact of new and small firms on job creation showed that small firms are the major source of employment growth in the United States. In new sectors such as information technology, as compared to service-producing or goods producing industries, the social and economic benefits of this job growth are especially obvious.

An important lesson from research done in the 1980s is that the businesses likely to drive the U.S. economy in the $21^{\text {st }}$ century will come from the efforts of nascent entrepreneurs starting companies, not from large established companies. We see the evidence of the same in today's context. Today's leading companies in the United States affirm the huge impact of entrepreneurs and the companies they start on the economy. These companies create more jobs, address important social issues such as unemployment and poverty, and increase the quality of life within the communities in which they are based. In a study of the entrepreneurial beginnings of 197 of the Fortune 500 companies, the National Commission on Entrepreneurship in the US found that the formation of new industries, creation of millions of new jobs, and the development of most new technologies was a function of whether new entrepreneurial firms were getting created. This study shows that in the IT industry, less than 25 years ago many of today's leading firms didn't even exist or they were small fledgling companies. Apple Computer, founded in 1978, achieved sales of more than $\$ 8$ billion by 2000 and employed approximately 95,000 individuals in many different countries by the second half of 2002. Microsoft Corporation, launched in 1976, is today the world's largest software company with more than $\$ 23$ billion in sales and employing more than 47,000 worldwide. Intel Corporation, founded less than 35 years ago - in 1969 - achieved record revenues of more than $\$ 33$ billion by 2000 and employing more than 83,000 by 2002 . This evidence that many new industries result from the formation, development, and growth of new entrepreneurial firms is convincing. Similarly, evidence can also be found in other industries, such as internet, biotechnology, fast food restaurants, discount retailing, and specialty fashion retailing, among others. The development of many companies in these industries, along with the industries themselves, can be traced to the creation and formation of new businesses by an entrepreneur. Fred Smith revolutionized the small package delivery system when he established Federal Express, the nationwide next-day delivery service. Wal-Mart, founded by Sam Walton, transformed retailing in the discount department store industry. Just 10 years ago, Jeff Bezos pioneered a new distribution channel that radically changed the way books and other products are sold when he launched Amazon.com on the Internet. These examples illustrate how individuals undertake the efforts necessary to initiate and start new businesses, create new industries and jobs, and trigger economic growth.

\section{The Role of Entrepreneurs in Saudi Arabia} economy:

Below are some facts and figures highlighting the significant role that SMEs may assume in the Saudi

- $\quad$ SMEs currently comprise $90 \%$ of business enterprises in the Kingdom. 
- $\quad$ SMEs are locally based and will provide one of the best strategies for meeting the Kingdom's goal of increasing the number and percentage of Saudi nationals in the work force.

- $\quad$ SMEs create 28 times more jobs per investment dollar than large firms.

- $\quad$ SMEs will need to overcome their historically weak financial performance - their gross margins to sales, sales per employee, and return on assets average only one-third that of larger firms.

- $\quad$ Small businesses in Saudi Arabia are the main source of private sector investment.

- Small businesses are a diverse group of businesses usually operating in the service, trade, and manufacturing sectors.

Small businesses are the primary source of creating jobs, alleviating poverty, fostering technological innovation, developing new products and services, and encouraging entrepreneurial culture. They are expected to contribute more than 50 percent of total industrial production in the near future.

\section{The Saudi Government Policies Regarding the Small and Medium Enterprises (SMEs)}

The Saudi government has expressed a clear and aggressive vision for the role of SMEs in the development process. Following is a summary of this vision as expressed in the Eighth Five-Year Economic Development Plan:

- $\quad$ The Kingdom cannot afford to increase public sector employment to meet the employment demand of an annual cohort of 200,000 school leavers. SMEs will have to provide almost all of the new job opportunities for this group. The Kingdom has identified the following strategies to improve SME growth and development:

- Develop markets for SME services rather than substituting public programs and institutions for them

- Ensure competition in the SME sector rather than allocating subsidies - train SMEs how to survive in the marketplace rather than subsidizing their operations

- Improve the impact of government assistance by collaborating with the private sector to deliver services

- $\quad$ Enhance the contribution of Saudi manpower in the development sectors, focus on upgrading their competency and productivity through training and re-training, and continue to replace foreign work force with Saudi workforce

- $\quad$ Place emphasis on the welfare of women, upgrade their capabilities, and remove the constraints which impede their participation in development activities in line with Islamic values and teachings

- $\quad$ The geographic distribution of SME in Saudi Arabia helps to achieve a more balanced growth of local economy and creates employment opportunities for local people in the national economy.

\section{Traits of Entrepreneurs}

The term "entrepreneur" has a lot of definitional and operational ambiguity (Gibb, 1990; House et al., 1993). Entrepreneurship literature can be classified into two definitions - the classical role and the psychological role, respectively - set by economists and behavioral scientists. This paper adopts the behavioral definition of entrepreneurs which defines the term with regard to his/her personality traits or characteristics that differentiates $\mathrm{him} / \mathrm{her}$ from non-entrepreneurs. The trait theory of entrepreneurship contends that certain attitudinal and behavioral factors differentiate entrepreneurs from non-entrepreneurs and successful entrepreneurs from the unsuccessful. Essentially this approach emphasizes the importance of the individual entrepreneur to the formation of a business. Palmer (1971) argues that in areas which possess capital and resources, while suffering from a scarcity of entrepreneurs, a lag in economic development is expected.

Previous empirical research suggests several traits of entrepreneurs, such as:

1. high need for achievement (DeCarlo \& Lyons, 1979; Hornaday \& Aboud, 1971; among many others)

2. $\quad$ internal locus of control (Hornaday \& Aboud, 1971)

3. $\quad$ high need for independence and effective leadership (DeCarlo \& Lyons, 1979; Hornaday \& Aboud, 1971)

4. $\quad$ high need for autonomy (DeCarlo \& Lyons, 1979; Sexton \& Bowman, 1983, 1984) 
5. $\quad$ information processing capability (McGaffey \& Christy, 1975)

6. $\quad$ preference for moderate level of risks (DeCarlo \& Lyons, 1979)

7. low conformity (DeCarlo \& Lyons, 1979; Sexton \& Bowman, 1983, 1984)

8. aggression, support, and benevolence (DeCarlo \& Lyons, 1979)

9. $\quad$ energy level, risk-taking, and change (Sexton \& Bowman, 1983, 1984)

10. dominance, endurance, innovation, self-esteem, low anxiety level, and cognitive structure (Sexton \& Bowman, 1983)

11. low interpersonal effect, social adroitness, low harm avoidance, and low succorance (Sexton and Bowman, 1984)

From the review of literature, it is observed that innovation, risk-taking propensity, energy level, and locus of control are more common and consistently reported traits among entrepreneurs. Thus, in this study, four separate traits are used to define the entrepreneurial profile - innovation, risk-propensity, internal locus of control, and energy level. These specific traits do not necessarily represent a comprehensive or definitional description of entrepreneurs. They do, however, appear repeatedly in economics, psychology, sociology, and entrepreneurship research and are representative of the personal characteristics necessary to meet the tasks and challenges of new venture creation. These were chosen from a number of alternative traits because they capture different facets of the entrepreneur as defined by the literature.

\section{Risk-taking}

Researchers have argued that the act of venture creation necessarily includes some level of personal financial and psychological risk (Kets de Vries, 1977). A number of researchers have provided empirical evidence in support of the view of entrepreneur as a risk-taker. Begley and Boyd (1987b), for example, found that business founders scored significantly higher than non-founders on risk-taking propensity and tolerance of ambiguity.

Risk-taking propensity can be effectively conceptualized as an individual's orientation toward taking chances in a decision-making scenario (Sexton and Bowman, 1985). Studies generally support the notion that risktaking is a predisposition and not simply a situational variable (Jackson et al., 1972; Plax and Rosenfeld, 1976).

Researchers have found empirical evidence in support of the view of an entrepreneur as a risk-taker. Begley and Boyd (1987b), for example, found that business founders scored significantly higher than non-founders on risktaking propensity and tolerance of ambiguity. However, it has also been observed that, in most cases, a greater propensity for risk is tempered by sound business judgment precluding risk-taking in the extreme. Thus, entrepreneurs are generally characterized as moderate risk-takers (Begley and Boyd, 1987b; Bird, 1989; Brockhaus, 1982; Sexton and Bowman, 1983). Based on the above discussion, we offer the following hypotheses:

H1: Entrepreneurs will exhibit a higher risk-taking propensity than will non-entrepreneurs.

\section{Innovativeness}

In the early stage of venture formation, innovativeness is an important trait to possess by the entrepreneurs (Bird, 1989). An innovative entrepreneur must have the ability to produce solutions in new situations. This is presumably linked with the entrepreneur's abilities attained through training and experience.

Researchers argue that value creation was the fundamental role of entrepreneurs; hence, the definition of an entrepreneur is an individual who exploits market opportunities through technical and/or organizational innovation (Tiessen, 1997). In defining the entrepreneur and distinguishing him or her from a small business owner, Carland et al. (1984) observe that "the entrepreneur is characterized principally by innovative behavior". As Drucker (1985) argues, creativity and innovation are conditions inherent in the role of entrepreneurship.

Entrepreneurs are significantly higher in innovativeness than is the general population. Not only do entrepreneurs have a higher preference for innovation than do managers (Robbins, 1986), but founders of rapid growth firms are significantly higher in personal innovation than are managers desiring innovative solutions to problems (Smith and Miner, 1983; Smith and Miner, 1984). 
H2: Entrepreneurs will exhibit a higher level of innovativeness than will non-entrepreneurs.

\section{Locus of Control}

According to Rotter (1966), the locus of control of an individual can be seen as either internal or external. An internal control expectation refers to control over one's own life, where the results of one's actions are considered to be dependent either on one's own behavior or on one's permanent characteristics. An external control expectation refers to the kind of attitude that focuses on the actions of other people or on fate, luck, or chance. According to Rotter's (1966) theory, the internal control expectation is related to learning and thus motivates and supports active striving. The external control expectation, on the other hand, impedes learning and encourages passivity. An internal control expectation is usually associated with entrepreneurial characteristics. Vesala (1992) has praised Rotter's (1966) hypothesis; in his opinion, Rotter captures something essential from the viewpoint of an entrepreneur; namely, the belief in one's own potentiality for influencing events.

Prior research has demonstrated that compared to non-entrepreneurs, entrepreneurs tend to exhibit higher internal locus of control (Begley and Boyd, 1987b). Based on the above evidence, we offer the following hypotheses:

H3: Entrepreneurs will exhibit a higher level of internal locus of control than will non-entrepreneurs.

Energy Level

Entrepreneurs are typically described as having high energy levels and working long hours associated with the founding and management of new businesses (Begley and Boyd, 1987b; Sexton and Bowman 1983). According to the JPI manual, 'energy level' is an individual's overall level of functioning in carrying out day-to-day activities. Someone scoring high on this scale is expected to be energetic in a variety of self-selected tasks and to demonstrate appreciable enthusiasm and endurance. Other attributes which describe entrepreneurs and correlate highly with the energy level construct include enterprising, initiative, energetic, persistent, and self confident (Jackson, 1994). Based on the above evidence, we offer the following hypotheses:

H4: Entrepreneurs will exhibit a higher energy level than will non-entrepreneurs.

\section{METHODOLOGY}

The current study utilized already established and reliable measures for the constructs under investigation. Table 1 provides a summary of the present study's measures and their reliabilities.

Table 1: The Reliability of the Study's Constructs

\begin{tabular}{|l|c|c|l|}
\hline \multicolumn{1}{|c|}{ Construct } & Number of Items & Cronbach's $\boldsymbol{\alpha}$ & \multicolumn{1}{c|}{ Source } \\
\hline Energy Level (ENL) & 13 & .78 & JPI Revised, 1994 \\
\hline Innovation (INV) & 20 & .77 & JPI Revised, 1994 \\
\hline Risk Taking (RSK) & 20 & .82 & Jackson, Hourany, \& Vidmar, 1972 \\
\hline Internal Locus of Control (LOC) & 23 & .91 & Rotter, 1966 \\
\hline
\end{tabular}

Sample

The survey instrument was distributed during the fall semester 2011 to students studying business, economics, and engineering and administered in a classroom setting by local professors who had agreed to participate in the research project and administer the survey in exchange for access to the survey data. The survey was translated from English to Arabic using the back translation technique by bilingual professors at the local institutions where the instrument was administered. A sample of 300 undergraduate students attending two major universities was selected for the purpose of the study. Of the total 300 surveys distributed, 240 were completed and used in the analysis yielding a response rate of $80 \%$. Table 2 provides summary of the demographic profile of the sample. 
Table 2: Demographic Profile

( $\mathbf{N = 2 4 0 )}$

Gender

Male

Female

Class:

Freshman

Sophmore

Juniors

Seniors

Major:

Business and other Humanities

Sciences

Family Business Ownership:

Yes

No

Participation in Family Business:

Yes

No

Current Ownership of Business:

Yes

No

Plans to Start Your Own Business:

During College

Immediately upon Graduation

5-10 years from Graduation

No Plans to own your own Business
$96.3 \%$

$3.8 \%$

$8.7 \%$

$12.2 \%$

$46.1 \%$

$33.1 \%$

$11.1 \%$

$88.9 \%$

$34.8 \%$

$65.2 \%$

$38.3 \%$

$61.7 \%$

$15.2 \%$

84.8

$16 \%$

$24.7 \%$

$21.1 \%$

$38.1 \%$

\section{RESULTS, DISCUSSION, IMPLICATIONS AND CONCLUSION}

The present study hypothesized that entrepreneurs possess higher levels of risk-taking propensity (H1), innovativeness $(\mathrm{H} 2)$, internal locus of control (H3), and energy (H4) than non-entrepreneurs. To test these hypotheses, a t-test was performed to find the difference of the mean responses along the four personality attributes between the two groups. Table 3 shows the mean response for each group along each of the four dimensions, as well as the standard deviations.

Table 3: Personality Differences of Entrepreneurs and Non-Entrepreneur

\begin{tabular}{|l|c|c|c|}
\hline \multirow{2}{*}{ Variable } & \multicolumn{2}{|c|}{ Means (Standard Deviations) of } & \multirow{2}{*}{ t-value } \\
\cline { 2 - 4 } & Entrepreneurs & Non-Entrepreneurs & $10.727^{*}$ \\
\hline Energy Level (ENL) & 3.6160 & 2.7060 & $(.60332)$ \\
& $(.54618)$ & 2.7398 & $11.203^{*}$ \\
\hline Innovation (INV) & 3.6487 & $(.57086)$ & $11.664^{*}$ \\
\hline Risk Taking (RSK) & $(.53245)$ & 2.5540 & $10.712^{*}$ \\
\hline Internal Locus of Control (LOC) & 3.5432 & $(.55964)$ & $(.61246)$ \\
\end{tabular}

* Significant at $<.01$ level

The results indicate that there are significant differences between entrepreneurs and non-entrepreneurs along the four personality variables examined in this study. As hypothized, entrepreneurs have higher propensity to take risk than non-entrepreneurs (mean scores are 3.54 and 2.55, respectively), thus confirming HI. The results also 
indicate that entrepreneurs are more innovative than non-entrepreneurs (means are 3.65 and 2.74, respectively), thus confirming H2. Similarly, entrepreneurs possess a higher level of internal locus of control than non-entrepreneurs (mean scores are 3.61 and 2.64, respectively), thus confirming H3. Finally, entrepreneurs were found to possess higher energy levels than non-entrepreneurs (means are 3.61 and 2.71, respectively), thus confirming H4.

These results hold several implications for educating and enhancing student entrepreneurs to pursue their dreams of owning their own businesses. If entrepreneurship is so important from economic and social points of view, can entrepreneurship be taught? Is there evidence that suggests that formal entrepreneurial training and business creation/success are related? The answer is positive. Growing evidence regarding the relationship between entrepreneurs' education, their businesses, and prospects of success is indicative of the importance of universitybased training for both graduate and undergraduate students. Owing to the many innovative ideas they possess, such students serve as "sources of potential entrepreneurs", especially in terms of creating new knowledge and technology-based businesses (Veciana, 2002). Acknowledging the role played by university environment in providing the initial training, motivation, and infrastructure for triggering and nurturing entrepreneurial activity within the younger population, many universities across the globe (and more specifically in developing countries) have started initiatives that offer training to the budding entrepreneurs (Streeter, Jacquette, and Hovitt, 2002). Such training can be immensely helpful during the early stage of the entrepreneur's business initiatives so that they can stand on their feet, grow, and play a significant role in nation's economy in years to come. Further, the abundance of education and training programs available to assist start-ups in the western countries attests to the influence schooling presumably has on the prevalence rates of nascent entrepreneurs. Research suggests that individuals who complete some additional education or training in business are more likely to be involved in the entrepreneurial process.

While entrepreneurship education is not as prevalent in the gulf region as it is in the western countries, evidence suggests that the need for entrepreneurship education in the gulf region is increasing. A case in point is Saudi Arabia. With the entry of the Kingdom in the WTO, it is going to open up markets to its products and services in other countries under more beneficial conditions. As a result, it is likely that many individuals want to capitalize on the newly opened markets, thus engaging in entrepreneurial activities. While entrepreneurship education in the gulf region at the university level (among GCC countries) may be termed to be in a nascent stage, we can see evidence of the fact that many governments in the region are increasingly appreciating the importance of such education in driving economic growth and creating forums. Such avenues provide opportunities for current or budding entrepreneurs to gather and gain knowledge, share ideas, and learn more about how one may identify opportunities and manage risks in the marketplace. For example, an organization named INJAZ Kuwait and founded in 2005 is active in the gulf region in providing entrepreneurial education for youth. It works with Kuwait's business and education sectors to deliver educational programs that nurture the entrepreneurial skills of young people and inspire the future generation of Kuwaiti business leaders. It offers a variety of programs, such as Banks in Action, The Company Program, The Entrepreneurship Masters Class, Personal Economics, and the Job Shadow that train young entrepreneurs in a variety of business skills. Interestingly, these programs are aimed at people from all educational backgrounds. Efforts put in by this organization are bearing fruits and it boasts of many success stories of its students starting new businesses in the gulf region (http://www.injaz-kuwait.org/success.html).

The Gulf Organization for Industrial Consulting (GOIC), in its role to facilitate the transfer of knowledge and to enhance the individual and organizational capacities for industrial development in the GCC member states, has developed an entrepreneurship education program in collaboration with the Tepper School of Business at Carnegie Mellon University (CMU). This high-level program brings together entrepreneurs, governments, and business managers in the field of biotech, information technology, and new ventures from all over the GCC to evaluate best practice examples in developing technology-based projects. The objective of the program is to provide the content and background required for starting and building new businesses and ventures. The program also places a special emphasis on introducing the participants to entrepreneurial thinking, idea generation, opportunity recognition, action, and execution via competitive positioning of products and services with a sustaining competitive advantage. It also trains individuals in the entire venture creation process, from idea generation to building viable global businesses, with special emphasis on the nurturing roles of corporations, governments, and foundations. Participants can also learn about areas, such as project appraisal and risk management, as a part of the training process. 
In summary, while entrepreneurship education in the western world is burgeoning, gulf states have started taking the first steps in this direction. While opportunities for continuing education for adults and entrepreneurs exist in some gulf states, there is a greater opportunity to create widespread university-level emphasis on offering such education to undergraduate and graduate students.

\section{AUTHOR INFORMATION}

Mohammad Al-Habib is an Assistant Professor of Marketing in the Faculty of Economics and Administration, King Abdulaziz University, Saudi Arabia. His research interest is focused on cross cultural consumer behavior, ethics and public policy. His research has appeared in several international journals including: International Marketing Review, Journal of Business Research and Journal of World Business. E-mail: habib@kau.edu.sa

\section{REFERENCES}

1. Begley, T., and Boyd, D. 1987a. A comparison of entrepreneurs and managers of small business firms. Journal of Management 13(1):99-108.

2. Begley, T., and Boyd, D. 1987b. Psychological characteristics associated with performance in entrepreneurial firms and smaller businesses. Journal of Business Venturing 2:79-93.

3. Birch, D.L. 1979. The job generation process. Cambridge, MA: M.I.T. Program on Neighborhood and Regional Change.

4. Bird, B. 1989. Entrepreneurial behavior Glenview, IL: Scott Foresman.

5. $\quad$ Brockhaus, R.H. 1982. The psychology of the entrepreneur. In C.A. Kent, D.L. Sexton, \& K.H. Vesper (Eds.), Encyclopedia of Entrepreneurship. Englewood Cliffs, NJ: Prentice Hall.

6. Carland, J.A., and Carland, J.W. 1991. An empirical investigation into the distinctions between male and female entrepreneurs and managers. International Small Business Journal 9(3):62-72.

7. Carland, J.W., Hoy, F., Boulton, W.R., and Carland, J.A. 1984. Differentiating entrepreneurs from small business owners: A conceptualization. Academy of Management Review 9:354-359.

8. Carland, J.W., III, Carland, J.W., Carland, J.A., and Pearce, J.W. 1995. Risk-taking propensity among entrepreneurs, small business owners, and managers. Journal of Business and Entrepreneurship 7(1):1523.

9. De Carlo, J., and Lyons, P. 1979. A comparison of selected personal characteristics of minority and nonminority female entrepreneurs. Journal of Small Business Management 17(4):22-29.

10. Drucker, P. 1985. Innovation and Entrepreneurship. New York: Harper and Row.

11. Gibb, A. 1990. Small business development in Central and Eastern Europe —Opportunity for a rethink? Journal of Business Venturing 8: 461-486.

12. Hallberg, K. 2000. “A Market Oriented Strategy for Small and Medium-Scale Enterprises," IFC discussion paper 40, April, Washington D.C.: The World Bank.

13. Herbig, P. and Kramer H., (1994). "The Effect of Information Overload on the Innovation Choice Process: Innovation Overload", Journal of Consumer Marketing, Vol. 11 Iss: 2, pp.45 - 54

14. House, Shamir, and Arthur (1993). "The Motivational Effects of Charismatic Leadership: A Self-Concept Based Theory", Organization Science, Vol. 4 No. 4, pp. 577 - 594

15. Jackson, D.N. 1967. Personality Research Form Manual. Goshen, NY: Research Psychologists Press.

16. Jackson, D.N. 1974. Personality Research Form Manual. Goshen, NY: Research Psychologists Press.

17. Jackson, D.N. 1994. Jackson Personality Inventory - Revised Manual. Port Heron, MI: Sigma Assessment Systems, Inc.

18. Jackson, D.N., and Guthrie, G.M. 1968. Multitrait-multimethod evaluation of the personality research form. Proceedings of the 76th Annual Convention of the American Psychological Association 3:177-178.

19. Jackson, D.N., and Lay, C. 1968. Homogenous dimensions of personality scale content. Multivariate Behavior Research 3(3):321-338.

20. Jackson, D.N., Hourany, L., and Vidmar, N.J. 1972. A four-dimensional interpretation of risktaking. Journal of Personality 40:433-501.

21. Kets de Vries, M.F.R. 1977. The entrepreneurial personality: A person at the crossroads. Journal of Management Studies 14(1): 34-57. 
22. McGaffey and Christy, (1975). "Information Processing Capability as a Predictory of Entrepreneurial Effectiveness", The Academy of Management, Vol. 18, No. 4, pp. 857 - 863

23. Palmer, M. (1971) The application of psychological testing to entrepreneurial potential. California Management Review, 13(3), 32-39.

24. Plax, T., and Rosenfeld, L. 1976. Correlates of risky decision-making. Journal of Personality Assessment 40:413-418.

25. Robbins, N.E. 1986. Entrepreneurial assessment: Characteristics which differentiate entrepreneurs, intrapreneurs, and managers. Doctoral dissertation, University of Minnesota, St. Paul, MN.

26. Rotter, J. B. (1966). Generalized expectancies for internal versus external control of reinforcement. Psychological Monographs, 80

27. Schumpeter, J.A. 1934, The Theory of Economic Development, Cambridge, MA: Harvard Press.

28. Sexton, D.L., and Bowman, N.B. 1983. Comparative entrepreneurship characteristics of students: Preliminary results. In J. Hornaday, J. Timmons, and K. Vesper, eds., Frontiers of Entrepreneurship Research. Wellesley, MA: Babson College, pp. 213-232.

29. Sexton, D.L., and Bowman, N.B. 1984. Personality inventory for potential entrepreneurs: Evaluation of a modified JPI/PRF-E test instrument. Proceedings of the Babson Entrepreneurship Research Conference, pp. 513-528.

30. Sexton, D.L., and Bowman, N.B. 1985. The entrepreneur: A capable executive and more. Journal of Business Venturing 1:129-140.

31. Smith, N.R., and Miner, J.B. 1983. Type of entrepreneur, type of firm, and managerial motivation: Implications for organizational life cycle theory. Strategic Management Journal 4:325-340.

32. Smith, N.R., and Miner, J.B. 1984. Motivational considerations in the success of technologically innovative entrepreneurs. In K.H. Vesper, ed., Frontiers of Entrepreneurship Research. Wellesley, MA: Babson College, pp. 488-495.

33. Streeter, D., Jacquette, J., and Hovis, K., 2002. "University-wide Entrepreneurship Education: Alternative Models and Current Trends," working paper, Department of Applied Economics and Management, Cornell University.

34. Tadeo, A.S. 2004. "An Assessment of the Business Environment for Micro and Small Scale Enterprises in Tanzania,” Journal of Small Business and Entrepreneurship, 17(3), 207-222.

35. Tiessen, J.H. 1997. Individualism, collectivism, and entrepreneurship: A framework for international comparative research. Journal of Business Venturing, 12: 367 - 384

36. Tolentino, A.L. 1995. "Enterprise Management: Guidelines for the Analysis of Policies and Programs for Small and Medium Enterprise Development, Geneva: International Labor Organization.

37. Veciana, J. 2002. "Comentarios sobre los resultados de la investigación comparada sobre la empresarialidad entre América Latina y el Este de Asia”, in Kantis, H. Ishida, M and Komori, M. (2002); Entrepreneurship in emerging economies: The Creation and Development of New Firms in Latin America and East Asia. Inter-American Development Bank, Department of Sustainable Development, Micro, Small and Medium Business Division.

38. Vesala, K. (1992), Pienyrittajien kontrollipremissit: Sosiaalipsykologinen tarkastelu, Acta Psychologica Fennica. Soveltavan psykologian monografioita 5, Suomen psykologinen seura, Helsinki.

39. http://www.injaz-kuwait.org/success.html

40. http://www.kauffman.org

41. http://www.kauffman.org/items.cfm?itemID=766 